absorbed through the ventral tube, and the lower the humidity the more rapidly was the stain taken up. The distal joints of, in particular, the hind limbs, which were immersed under these conditions, also became stained.

On agar blocks, where only the tips of the legs and the ventral tube vesicles were in continuous contact with the agar surface, in a low humidity the animals survived for a much longer period than when in the same humidity but on a dry surface. The extrusion of the vesicles was only sufficient to reach the surface of the agar and no action of the vesicles comparable with that observed in Sminthurus viridis by Davies, has been seen. Puncturing the vesicles had the effect of reducing greatly the length of life except in a saturated atmosphere.

Onychiurus armatus apparently has no mechanism for preventing water loss, and the ventral tube vesicles seem to be the primary water-absorbing organs.

University College of the South-West,

S. R. Nutrman.

Exeter.

July 3.

1 Davies, W. M., Brit. J. Exp. Biol., 6, No. 1 (1928).

\section{Relative Growth in the Individual}

WITH regard to A. E. Needham's communication ${ }^{1}$ stressing the desirability of obtaining relative growth data on individuals as distinct from contemporaneous data obtained in populations, we would like to point out that such data relating to guinea pigs were published by us some time ago ${ }^{2}$. We then demonstrated the isometry of teat-length against bodylength in the young male guinea pig and the occur. rence of 'simple' allometry of the teat under androgenic stimulation. In these experiments data for groups of comparable individuals were averaged.

More recently ${ }^{3}$ we have published a preliminary account of teat-growth data obtained on individual goats, showing that in the young female a phase of teat isometry is succeeded by a phase of 'simple' positive allometry; the constant $\alpha$ was found to vary among individuals. A more detailed account of these last observations is in the press ${ }^{4}$.

$$
\text { S. J. Folley. }
$$

National Institute for Research

A. C. Bottomley.

in Dairying,

University of Reading. July 14

${ }^{1}$ Needham, A. E., NATURE, 148, 52 (1941).

Bottomley, A. C., and Folley, S. J., Proc. Roy. Soc., B, 126, 224 (1938).

- Folley, S. J., and Bottomley, A. C., J. Physiol., 99, 5 P (1941).

- Folley, S. J., Scott Watson, H. M., and Bottomley, A. C., J. Dairy Res. (1941). (In the press.)

\section{Miocene Deposits in Kenya}

IN $1935 \mathrm{I}$ examined the Miocene deposits of Kavirondo, Kenya, but as publication of results (already overdue) seems likely to be further delayed, I should be grateful for an opportunity to summarize the more important results with reference to misconceptions which have arisen about the age of the formation and its fauna.
The deposits are exposed in three main areas: Rusinga, an island on the edge of Lake Victoria, Karungu, originally described by Oswald ${ }^{1}$, and Koru, farther east. The rocks are largely volcanic in origin, and in each case are associated with a major volcanic centre. On Rusinga the lower beds are fossiliferous clays with thin sandstones containing a small proportion of tuffaceous material; these are succeeded by tuffs with an intercalation of red clays and thin limestones, and the tuffs overlain in turn by agglomerate and nephelinite lava. The tuffs and agglomerates thicken rapidly towards the south-west, indicating as source the Gwasi volcanic centre of South Kavirondo. Adjacent islands provide confirmatory evidence of this. Karungu lies on the southern fringe of the same volcanic mass, and the fossiliferous beds there are correlated with the lowest beds of Rusinga. Koru shows a succession broadly similar to Rusinga, but red clays with limestones in the middle part provide the main fossiliferous horizon.

Bailey Willis ${ }^{2}$ has argued that the Karungu deposits are fluviatile Pliocene, containing occasional derived Miocene fossils, and Broom $^{3}$ has recently queried the Miocene age of Proconsul from Koru on systematic grounds. It is therefore necessary to confirm, first, that the fossiliferous part of the formation is definitely lacustrine, secondly, that the fossils are truly autochthonous, being in some cases articulated and in most cases quite unrolled, and thirdly, that Dr. A. T. Hopwood and D. G. MacInnes, who have separately worked on the fauna, are quite satisfied that it is of Lower Miocene date.

Independent evidence indicating considera,ble age is provided by the later history of the deposits. On Rusinga the beds show strong deformation, including isoclinal folding and thrusting with production of phacoidal structures, which it is exceedingly difficult to explain other than by lateral compression (in this connexion Willis's theory of an expanding disk beneath Lake Victoria as the force which produced the Rift Valleys should be remembered). In particular, it may be emphasized that the phenomena are quite distinct from those of slumping, welldeveloped in neighbouring Pleistocene beds. Afterwards the deposits were intruded by igneous dykes, and in the west extensively eroded with relation to a base level beneath the present lake before the formation of high-level raised beaches in the Lower and Middle Pleistocene. Between deposition of the fossiliferous beds and the Lower Pleistocene, therefore, accumulation of up to $500 \mathrm{ft}$. of tuffs and agglomerates, extrusion of lava, disturbance of the beds, dyke intrusion and extensive erosion successively occurred, which supports the palæontological evidence in suggesting a date at least as early as Miocene.

This early disturbance of the African peneplain, previously doubted by some authorities, is further illustrated by the discovery of phonolite-covered Lower Miocene beds in a valley cut in the gneiss of the northern scarp of the Kavirondo Rift, which must, accordingly, be of pre-Miocene age.

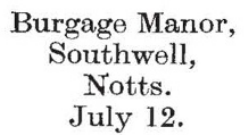

P. E. KENT.

${ }^{1}$ Quart. J. Geol. Soc., 70, 128-162 (1914).

2 "East Afriean Plateaus and Rift Valleys", pp. 148-150 (1936).

${ }^{3}$ NATURE, 148, 14 (1941). 